\title{
PEMBERDAYAAN PENGRAJIN BAMBU DI KELURAHAN KINILOW KECAMATAN TOMOHON UTARA KOTA TOMOHON
}

\author{
Afny Rompas \\ Jenny Baroleh \\ Noortje Marsellanie Benu
}

Naskah diterima melalui Email Jurnal Ilmiah agrisosioekonomi@unsrat.ac.id

: Sabtu, 24 Oktober 2020

Disetujui diterbitkan

: Rabu, 28 Oktober 2019

\begin{abstract}
This study aims to determine the empowerment of bamboo craftsmen in Kinilow Village. The research was conducted from October to December 2019. The data used are primary and secondary data. Primary data were obtained through interview surveys using questionnaires and documentation. Secondary data were obtained from literature studies and related agencies, namely the Tomohon Industry and Trade Office and the Kinilow Urban Village government. The sampling method was purposive (purposive sampling) on 7 respondents of bamboo craftsmen in Kinilow Village. The data analysis used in this research is descriptive qualitative analysis and the data obtained are presented in tabular form. The results showed that the process of empowering bamboo craftsmen in Kinilow Village occurred through the implementation of empowerment which included the awareness and behavior formation stage, the knowledge transformation stage, and the intellectual ability improvement stage. The implementation of empowerment is carried out through entrepreneurship training which includes two objectives, namely providing counseling to improve product quality and providing training in product development skills and marketing strategies. As well as assistance provided by the Dinas.
\end{abstract}

Keywords: skills, development, bamboo handicrafts, entrepreneurship

\section{ABSTRAK}

Penelitian ini bertujuan untuk mengetahui pemberdayaan pengrajin bambu di Kelurahan Kinilow. Penelitian dilaksanakan pada bulan Oktober sampai Desember 2019. Data yang digunakan adalah data primer dan sekunder. Data primer diperoleh melalui survei wawancara dengan menggunakan kuesioner serta dokumentasi. Data sekunder di peroleh dari studi literatur dan instansiinstansi yang berkaitan yaitu Dinas Perindustrian dan Perdagangan Kota Tomohon dan pemerintah Kelurahan Kinilow. Metode pengambilan sampel secara sengaja (purposive sampling) pada 7 responden pengrajin bambu di Kelurahan Kinilow. Analisis data yang digunakan dalam penelitian ini yaitu analisis deskriptif kualitatif dan data yang diperoleh disajikan dalam bentuk tabel. Hasil penelitian menunjukkan bahwa proses pemberdayaan pengrajin bambu di Kelurahan Kinilow terjadi melalui pelaksanaan pemberdayaan yang meliputi tahap penyadaran dan pembentukan perilaku, tahap transformasi kemampuan pengetahuan, dan tahap peningkatan kemampuan intelektual. Pelaksanaan pemberdayaan dilakukan melalui pelatihan kewirausahaan yang meliputi dua sasaran yaitu pemberian penyuluhan untuk meningkatkan kualitas produk dan memberikan pelatihan keterampilan pengembangan dan strategi pemasaran produk. Serta pendampingan yang dilakukan oleh Dinas.

Kata kunci :keterampilan, pengembangan, kerajinan bambu, kewirausahaan 


\section{PENDAHULUAN}

\section{Latar Belakang}

Program pemberdayaan masyarakat merupakan salah satu cakupan program pendidikan luar sekolah yang dapat memberikan kontribusi besar dalam upaya pembangunan masyarakat. Kegiatan pemberdayaan masyarakat dilaksanakan dengan fokus untuk membuat masyarakat mandiri dalam usaha memberdayakan lingkungan dan potensi-potensi yang dimiliki masyarakat agar tercapai kualitas hidup yang baik (Paharizal, 2017).

Kegiatan kerajinan tangan menjadi salah satu program kegiatan yang memiliki kontribusi yang besar bagi pemberdayaan pengrajin bambu di desa. Kerajinan tangan adalah kegiatan seni yang mengolah bahan-bahan tertentu menjadi produk yang tidak hanya bermanfaat tetapi juga mengandung nilai-nilai estetika (Nasir, 2013).

Salah satu kerajinan bambu yang dapat membuat dan menjual kerajinan bambu ini adalah usaha kerajinan bambu yang ada di Kinilow. Jumlah usaha kerajinan bambu di Kinilow ada 12 pengrajin dan usaha ini telah ada sejak tahun 1987 dan telah dilakukan dari generasi ke generasi. Usahanya sekitar 33 Tahun, potensi dari sumber daya alam (SDA) seperti bahan baku yang melimpah atau mudah didapat, tanaman bambu dan sumber daya manusia (SDM) seperti keterampilan yang sudah ada turun temurun.

\section{Rumusan Masalah}

Berdasarkan latar belakang yang telah dikemukakan maka permasalahan dalam penelitian ini ialah bagaimana pemberdayaan pengrajin bambu di Kelurahan Kinilow?

\section{Tujuan Penelitian}

Penelitian ini bertujuan untuk mengetahui pemberdayaan pengrajin bambu di Kelurahan Kinilow.

\section{Manfaat Penelitian}

Bagi peneliti, untuk meningkatkan pengetahuan tentang pemberdayaan pengrajin bambu. Bagi pembaca dapat menjadi sumber informasi dan masukan yang dapat digunakan dalam penelitian selanjutnya. Bagi pengrajin bambu, dapat digunakan sebagai pengetahuan untuk meningkatkan usaha pengrajin bambu. Bagi
Pemerintah, sebagai bahan masukan untuk menetapkan kebijakan-kebijakan dalam keputusan untuk meningkatkan pemberdayaan pengrajin bambu secara khusus dan masyarakat secara umum.

\section{METODE PENELITIAN}

\section{Waktu dan Tempat Penelitian}

Penelitian ini dilakukan selama tiga bulan, yaitu bulan Oktober sampai bulan Desember 2019, yang dimulai dari persiapan sampai penyusunan laporan. Penelitian ini dilaksanakan di Kelurahan Kinilow, Kecamatan Tomohon Utara, Kota Tomohon.

\section{Pengambilan Data}

Data yang dipergunakan dalam penelitian ini adalah data primer dan data sekunder. Data primer diperoleh melalui survei wawancara dengan menggunakan kuesioner yang sudah di persiapkan serta dokumentasi. Data sekunder di peroleh dari studi literatur dan instansi-instansi yang berkaitan yaitu Dinas Perindustrian dan Perdagangan Kota Tomohon dan pemerintah Kelurahan Kinilow.

\section{Pengambilan Sampel}

Pengambilan sampel yang digunakan dalam penelitian ini adalah metode pengambilan sampel secara sengaja (purposive sampling) pada 7 responden pengrajin bambu di Kelurahan Kinilow.

\section{Konsep Pengukuran Variabel}

Variabel yang diukur dalam penelitian ini adalah:

1. Karakteristik Responden

2. Karakteristik Usaha

3. Pemberdayaan Pengrajin Bambu di

Kinilow dikaji berdasarkan :
a). Pelaksanaan Pemberdayaan
b). Pelatihan
c). Strategi Pemasaran Produk

\section{Metode Analisis Data}

Analisis data yang digunakan dalam penelitian ini yaitu analisis deskriptif kualitatif dan data yang diperoleh disajikan dalam bentuk tabel. 


\section{HASIL DAN PEMBAHASAN}

\section{Gambaran Umum Lokasi Penelitian}

Kota Tomohon terkenal dengan destinasi wisata kerajinan bambu yang berlokasi di Jalan Raya Tomohon-Kinilow, Tomohon Utara, Kota Tomohon, Sulawesi Utara. Tempat ini tidak sulit ditemukan karena berada di pinggiran jalan raya Manado-Tomohon.

Letak usaha ini berada di Kelurahan Kinilow lingkungan V (lima), dengan batasbatas wilayah sebagai berikut:
a. Sebelah Utara berbatasan dengan kelurahan Tinoor Satu.
b. Sebelah Timur berbatasan dengan kelurahan Kinilow Satu.
c. Sebelah Selatan berbatasan dengan kelurahan Kinilow Satu.
d. Sebelah Barat berbatasan dengan Hutan Lindung Lokon.

\section{Karakteristik Responden}

\section{Karakteristik Responden Menurut Tingkat Umur}

Berdasarkan temuan dilapangan, maka peneliti telah mewawancarai sebanyak 7 orang pemilik yang berasal dari seluruh pemilik pengrajin bambu. Komposisi responden menurut umur, dapat dilihat pada Tabel 1.

\begin{tabular}{ccr} 
Tabel 1. Responden Berdasarkan Umur & \\
\hline Umur (Tahun) & Jumlah Responden & Persentase (\%) \\
\hline $20-40$ & 1 & 14,28 \\
$41-60$ & 3 & 42,86 \\
$61-80$ & 3 & 42,86 \\
\hline Total & 7 & 100.00 \\
\hline
\end{tabular}

Sumber : Diolah dari Dari Primer, 2019

Tabel 1 menunjukkan bahwa data yang diperoleh dan diolah berdasarkan tanggapan responden di dalam kuesioner tidak ada data yang hilang atau tidak terinput, dapat dilihat dari total jumlah respondem 7 orang dengan persentase $100 \%$, dan nampak dari tabel antara umur 20 sampai 40 tahun hanya berjumlah 1 responden saja dengan persentase $14,28 \%$, kemudian antara umur 41 sampai 60 tahun berjumlah 3 responden dengan persentase $42,86 \%$, dan antara umur 61 sampai 80 ada 3 responden dengan persentase $42,86 \%$. Hal ini menunjukkan usia responden yang terbanyak ada di antara 41 sampai 60 tahun dan 61 sampai 80 tahun dengan jumlah masing-masing 3 responden.

\section{Karakteristik Responden Menurut Jenis Kelamin}

Pemberdayaan pengrajin bambu dari 7 responden dapat dibedakan berdasarkan jenis kelamin. Kriteria responden berdasarkan jenis kelamin dapat dilihat pada Tabel 2.

\begin{tabular}{lcr}
\multicolumn{2}{c}{ Tabel 2. Responden Menurut Jenis Kelamin } \\
\hline Jenis Kelamin & Jumlah Responden & Persentase (\%) \\
\hline Laki-laki & 1 & 14,28 \\
Perempuan & 6 & 85,72 \\
\hline \multicolumn{1}{c}{ Total } & 7 & 100 \\
\hline
\end{tabular}

Sumber : Diolah dari Data Primer, 2019

Tabel 2 menunjukkan bahwa responden berdasarkan jenis kelamin yang paling banyak yaitu perempuan berjumlah 6 orang dengan persentase $85,72 \%$ dan laki-laki sebanyak 1 orang dengan persentase $14,28 \%$. Hal ini menunjukkan bahwa jenis kelamin responden didominasi oleh perempuan.

\section{Karakteristik Responden Menurut Tingkat Pendidikan}

Kriteria responden berdasarkan tingkat pendidikan yang bertujuan untuk mengetahui mayoritas tingkat pendidikan responden dapat dilihat pada Tabel 3.

Tabel 3. Responden Menurut Tingkat Pendidikan

\begin{tabular}{ccr}
\hline Pendidikan & Jumlah Responden & Persentase (\%) \\
\hline SD & 3 & 42,86 \\
SMP & 2 & 28,57 \\
SMA/SMK & 2 & 28,57 \\
\hline Total & 7 & 100 \\
\hline Sumber : Diolah dari Data Primer, Tahun 2019
\end{tabular}

Tabel 3 menunjukkan bahwa rata-rata pendidikan responden yaitu SD sebanyak 3 responden dengan persentase $42,86 \%$, SMP berjumlah 2 responden dengan persentase $28,57 \%$, dan SMA berjumlah 2 responden dengan persentase $28,57 \%$. Dapat dilihat bahwa responden yang paling banyak dengan tingkat pendidikan adalah SD sebanyak 3 orang dengan persentase $42,86 \%$.

\section{Lama Usaha}

Bisnis kerajinan bambu ini sudah ada sejak puluhan tahun, bahkan dijalankan secara turuntemurun mulai dari pemuda hingga orang tua. Jangka waktu lamanya para pengrajin bambu di Kelurahan Kinilow dapat dilihat pada Tabel 4. 
Tabel 4. Lama Usaha Pengrajin Bambu

\begin{tabular}{ccr}
\hline Lama Usaha (Tahun) & Jumlah Responden & Persentase (\%) \\
\hline $1-15$ & 4 & 57,15 \\
$16-30$ & 2 & 28,57 \\
$31-45$ & 1 & 14,28 \\
\hline Total & 7 & 100 \\
\hline
\end{tabular}

Sumber : Diolah dari data Primer, 2019

Tabel 4 menunjukkan bahwa lama usaha antara 1 sampai 15 tahun ada 4 responden dengan persentase $57,15 \%$, kemudian antar 16 sampai 30 tahun jumlah responden 2 orang dengan persentase $28,57 \%$, dan antara 31 sampai 45 tahun ada 1 responden dengan persentase $14,28 \%$. Dapat dilihat lama usaha yang paling banyak terdapat pada 1 sampai 15 tahun dengan jumlah responden 4 orang dengan hasil persentase $57,14 \%$.

\section{Bahan Baku}

Bahan baku merupakan aspek yang sangat penting agar dapat menghasilkan suatu produk yang dapat dipakai. Untuk bahan baku yang digunakan oleh usaha ini berdasarkan hasil wawancara dengan pihak yang terkait yaitu bambu tambelang yang mempunyai sifat kuat, lurus, ringan dan mudah dibelah. Ketersediaan dan perolehan bahan baku yang digunakan para pengrajin dalam memproduksi kerajinan bambu dapat dilihat pada Tabel 5.

Tabel 5. Ketersediaan dan Perolehan Bahan Baku

\begin{tabular}{ccc}
\multicolumn{4}{c}{ Tabel 5. Ketersediaan dan Perolehan Bahan Baku } \\
\hline Perolehan Bahan Baku & Jumlah Responden & Persentase (\%) \\
\hline Penjual Bambu & 3 & 42,86 \\
Kebun sendiri \& Penjual Bambu & 4 & 57,14 \\
\hline Total & 7 & 100 \\
\hline Sumber : Diolah dari Data Primer, 2019 &
\end{tabular}

Tabel 5 menunjukkan bahwa ketersediaan bahan baku dalam proses produksi selalu ada atau tersedia, yang memperoleh bahan bakunya dari penjual bambu ada 3 responden dengan persentase $42.86 \%$ dan yang memperoleh bahan bakunya dari kebun bambu mereka sendiri serta penjual bambu ada 4 responden dengan persentase 57,14\%, sedangkan yang dari kebun sendiri tidak ada.

\section{Tenaga Kerja}

Tenaga kerja dalam usaha kerajinan bambu di Kinilow masih berasal dari dalam keluarga yaitu ada bapak, ibu, anak dan saudara. Jumlah tenaga kerja pengrajin bambu dapat dilihat pada Tabel 6 .
Tabel 6. Jumlah Tenaga Kerja

\begin{tabular}{ccr}
\hline Tenaga Kerja & Jumlah Responden & Persentase (\%) \\
\hline $1-3$ & 5 & 71,43 \\
$4-6$ & 2 & 28,57 \\
\hline Total & 7 & 100 \\
\hline
\end{tabular}

Sumber : Diperoleh dari Data Primer, 2019

Tabel 6 menunjukkan bahwa jumlah tenaga kerja dari 1 sampai 3 orang yaitu sebanyak 5 responden dengan perolehan persentase terbanyak yaitu $71,43 \%$, dan perolehan jumlah tenaga kerja sebanyak 4 sampai 6 responden dengan perolehan persentase terendah $28,57 \%$.

\section{Modal}

Penggunaan modal dalam usaha ini tergolong kecil karena masih berskala rumah tangga, dimana untuk biaya bahan bakunya yang sangat murah dan tenaga kerja yang tidak dibayar karena masih menggunakan anggota keluarganya. Ada yang masih menggunakan modal sendiri atau secara pribadi, ada juga yang sudah melakukan pencatatan keuangan dan telah menjalin hubungan dengan lembaga keuangan dalam peminjaman modal seperti di koperasi. Sumber penggunaan modal pengrajin bambu dapat dilihat pada Tabel 7 .

Tabel 7. Penggunaan Modal

\begin{tabular}{ccr}
\hline Sumber Modal & Jumlah Responden & Persentase (\%) \\
\hline Koperasi & 6 & 85,72 \\
Modal Sendiri & 1 & 14,28 \\
\hline Total & 7 & 100 \\
\hline Sumber : Diolah dari Data Primer, 2019 &
\end{tabular}

Tabel 7 menunjukkan bahwa sebanyak 85,72\% dengan jumlah 6 responden menggunakan modal peminjaman dari koperasi, dan yang masih menggunakan modal sendiri hanya 1 responden dengan persentase $14,28 \%$. Proses produksi dari usaha ini masih menggunakan alat sederhana seperti pisau, parang, gergaji, dan gunting. Ada juga yang menggunakan alat teknologi seperti mesin skap dan gurinda.

\section{Produksi}

Proses menganyam masih dilakukan secara manual dengan menggunakan tangan. Pengrajin memiliki cara sederhana dalam proses mengawetkan produk yang dihasilkan yaitu dengan cara pengasapan diatas api sehingga produknya pun memiliki daya tahan yang lama. Produk nyiru mampu bertahan selama 1 tahun bahkan lebih dari setahun untuk pemakaiannya. 


\begin{tabular}{lcr}
\multicolumn{2}{l}{ Tabel 8. Alat Produksi } & \\
\hline $\begin{array}{c}\text { Alat Produksi } \\
\text { Yang Digunakan }\end{array}$ & Jumlah Responden & Persentase (\%) \\
\hline Alat Tradisional & 6 & 85,72 \\
$\begin{array}{c}\text { Alat Tradisional \& } \\
\text { Modern }\end{array}$ & 1 & 14,28 \\
\hline Total & 7 & 100 \\
\hline
\end{tabular}

Sumber : Diolah dari Data Primer, 2019

Tabel 8 menunjukkan bahwa yang menggunakan alat produksi tradisional berjumlah 6 responden dengan persentase $85,72 \%$, dan yang menggunakan alat tradisional serta modern ada 1 responden dengan persentase $14,28 \%$.

\section{Harga Bahan Baku dan Harga Pemasaran}

Bahan baku yang didapatkan dari hasil kebun sendiri dan atau dari penjual bambu, jenis bambu yang dipakai yaitu bambu Tambelang dengan kualitas yang baik karena merupakan salah satu jenis bambu yang dapat diolah untuk dijadikan kerajinan bambu, karena seratnya lebih lentur, kadar air sedikit, tekstur lebih halus, serta ukurannya lebih panjang. Bahan baku ini dibeli dari para pedagang petani atau penjual bambu dan dari hasil kebun sendiri dengan harga bahan baku seujung bambu yang terdiri dari 8 ruas yaitu berkisar antara Rp 6.000 sampai Rp 10.000 .

Jenis hasil produksi yaitu nyiru, tolu (topi petani), tempat ayam, keranjang buah, penutup saji, lampion, kursi, meja, baki.

Harga yang ditawarkan juga tergolong murah dan beragam, tergantung jenis dan ukuran. Untuk hiasan mulai dari harga Rp 25.000 hingga $\mathrm{Rp}$ 50.000. Jika ingin motif yang lain bisa memesan langsung. Untuk produk yang paling banyak dibeli yaitu nyiru harganya berkisar antara Rp 25.000 hingga Rp 35.000 per unit.

\section{Lokasi Usaha}

Lokasi usaha kerajinan bambu berlokasi di di Kinilow dan banyak didatangi oleh pembeli atau konsumen dari luar negeri yang kebetulan lewat dan singgah mampir. Setiap tahunnya jumlah pembeli dari luar negeri semakin meningkat terutama pada saat perayaan festival bunga yang diselenggarakan di Kota Tomohon pada bulan Agustus. Hal ini terjadi karena semakin dikenalnya oleh masyarakat luar negeri festival bunga ini serta cenderamatanya yaitu kerajinan bambu yang ada di
Kinilow. Selain itu juga, pembeli dari masyarakat lokal pun mengalami peningkatan terutama pada saat ada kegiatan lomba di lingkungan tempat tinggal dalam menyambut hari raya Paskah dan hari raya Natal.

Lokasi usaha kerajinan bambu ini berada pada tempat yang tidak aman dari bencana longsor karena berada pada pinggiran sungai yang terjal dibelakangnya dan tanah yang bertebing didepannya. Hal ini tentu sangat beresiko bagi keselamatan pekerja. Oleh karena itu, ada wacana dari pemerintah setempat untuk merelokasi usaha ini ketempat yang lebih aman.

\section{Pemberdayaan Pengrajin Bambu}

Pemberdayaan Pengrajin Bambu di Kinilow dikaji berdasarkan pelaksanaan pemberdayaan, yang dilakukan secara bertahap yaitu tahap penyadaran dan pembentukkan perilaku, tahap transformasi dan tahap peningkatan intelektual. Pelatihan kewirausahaan yang terbagi juga dalam dua sasaran yaitu Pemberian penyuluhan untuk meningkatkan kualitas produksi dan memberikan pelatihan keterampilan pengembangan. strategi pemasaran produk dan pendampingan.

Pelaksanaan pemberdayaan masyarakat melalui tiga tahapan yaitu tahap penyadaran dan pembentukan perilaku, tahap penyadaran dilakukan melalui kegiatan penyuluhan dan kegiatan komunikasi dialogis. Tahap penyadaran dan pembentukan perilaku merupakan tahap persiapan dalam proses pemberdayaan. Pada tahap ini pihak pemberdaya atau pelaku pemberdayaan berusaha menciptakan prokondisi, supaya dapat memfasilitasi berlangsungnya proses pemberdayaan yang efektif. Tahap penyadaran akan lebih membuka keinginan dan kesadaran pengrajin tentang kondisinya saat itu, dan dengan demikian akan dapat merangsang kesadaran mereka tentang perlu memperbaiki kondisi untuk menciptakan masa depan yang lebih baik. Tahap Transformasi, jika tahapan penyadaran sudah dilakukan tahapan transformasi pengetahauan ini menjadi bagian yang juga sangat penting dalam mengembangkan potensi yang ada dalam diri kita. Metode yang digunakan dalam mentransformasikan pengetahuannya itu melalui metode ceramah. Penyampaian materi diberikan menggunakan metode ceramah agar memudahkan peserta didik dalam menangkap atau mencerna materi yang diberikan kemudian dari materi yang sudah 
dipahami oleh peserta didik diterapkan melalui praktek. Tahap Peningkatan Intelektual. Tahap ini berupa untuk membentuk kecakapan keterampilan sehingga terbentuklah inisiatif dan kemampuan inovatif untuk menghantarkan pada kemandirian.

Pelatihan kewirausahaan terbagi juga dalam dua sasaran yaitu pemberian penyuluhan untuk meningkatkan kualitas produk dan, memberikan pelatihan keterampilan pengembangan. Pelatihan pemberian penyuluhan untuk meningkatkan kualitas produksi tentang kewirausahaan agar pengrajin dapat menciptakan inovasi dalam produknya sehingga tertarik untuk mengikuti pelatihan. Kemudian memberikan pelatihan keterampilan pengembangan berupa pengembangan desain dan pelatihan membuat pembukuan supaya para pengrajin dapat mengembangkan pola dan bentuk dalam pembuatan kerajinan bambu, agar model kerajinan bambu bervariasi serta pengrajin mampu membuat pembukuan sederhana, sehingga pengrajin dapat mengetahui laba serta pengeluarannya.

Strategi pemasaran produk dilakukan ditempat produksinya saja dengan menunggu konsumen yang singgah atau mampir di tempat kerajinan bambu baik dari pengendara yang melintasi jalan pintu masuk ke Tomohon serta melalui kegiatan pameran. Pengrajin mengikuti pameran yang diselenggarakan pada saat adanya kegiatan TIFF (Tomohon International Festival Flower) dan Manado Fiesta.

Pendampingan yang dilakukan oleh dinas yaitu dengan ikut langsung dalam proses kegiatan dan melakukan proses memantau, memberikan arahan, mengajarkan dan melatih tenaga kerja dalam proses pembuatan kerajinan bambu.

\section{KESIMPULAN DAN SARAN}

\section{Kesimpulan}

Berdasarkan hasil penelitian tentang Pemberdayaan Pengrajin Bambu di Kelurahan Kinilow, dapat disimpulkan bahwa Proses pemberdayaan pengrajin bambu di Kelurahan Kinilow terjadi melalui pelaksanaan pemberdayaan yang meliputi tahap penyadaran dan pembentukan perilaku, tahap transformasi kemampuan pengetahuan, dan tahap peningkatan kemampuan intelektual. Pelaksanaan pemberdayaan dilakukan melalui pelatihan kewirausahaan yang meliputi dua sasaran yaitu pemberian penyuluhan untuk meningkatkan kualitas produk dan memberikan pelatihan keterampilan pengembangan dan strategi pemasaran produk. Serta pendampingan yang dilakukan oleh Dinas.

\section{Saran}

Diharapkan peran pemerintah dalam hal ini dari Dinas Perindustrian dan Perdagangan Kota Tomohon dalam pelaksanaan pelatihan-pelatihan dalam hal pemberdayaan pada pengrajin bambu sehingga ada inovasi-inovasi baru yang dapat dipraktekkan pengrajin bambu.

\section{DAFTAR PUSTAKA}

Nasir N Yopi. 2013. Gerbang Kreativitas: Jagat Kerajinan Tangan. Jakarta: PT Bumi Aksara.

Paharizal R Kusumawiranti. 2017. Pemberdayaan Masyarakat Berbasis Pengolahan Bambu di Kecamatan Minggir, Kabupaten Slamen Yogyakarta. Universitas Widya Mataram Yogyakarta. 